\title{
SERBIAN MEDIAEVAL LAW ON WILLS AND SUCCESSION
}

\begin{abstract}
Serbian legal sources have limited data on the law of wills and succession: no will was preserved and the Law Code of Stefan Dušan regulated intestate succession only in articles 41 and 48. It seems that the commoner class (sebri), living mostly in extended families, inherited their property according to the rules of customary law, while the noblemen accepted provisions of Byzantine law.

In Serbian legal miscellanies, translated from Greek, the institutes of testate and intestate succession were thoroughly presented. The so called Zakon gradski (Serbian translation of Procheiron) contains 12 chapters referring to the law of succession and the Syntagma of Matheas Blastares placed all provisions on testate and intestate succession in chapter $K-12$ under the title "On heirs and the disherison of sons or parents".

Byzantine law on intestate succession kept all the basic principles of Justinian's legislation. Serbian sources only mention intestate succession of hereditary estates (socalled baština) belonging to the noblemen class, but according to some fragments from Serbian charters we can conclude that the estates could be inherited even in the commoner's class.

The fact that not a single will remained in Serbian mediaeval law does not mean that it was unknown in Serbia. Sources mention its existence using Slavonic terms "zavet" and "zaveštanije" and sometimes a Greek word "diatax", while a freedom of disposition by testament was expressed by the formula "given for the soul" ("za dušu odati").
\end{abstract}

Key words: $\quad$ Law Code of Stefan Dušan, Procheiron, “Zakon gradski”, Syntagma of Matheas Blastares, testate succession, intestate succession, will.

\section{Introduction: Testate and Intestate Succession}

Where a deceased person left a will (testamentum) and succession took place according to the terms of that will the succession was said to be testate. Where the deceased person did not leave a will succession was said to be intestate. The general rule of Roman law was that no one could die

* Professor-Retired, University of Novi Sad School of Law e-mail: srdjansarkic@gmail.com 
partly testate, partly intestate (nemo pro parte testatus, pro parte intestatus decedere potest).

Serbian legal sources have limited data on the law of wills and succession: no will was preserved and the Law Code of Stefan Dušan regulated intestate succession only in articles 41 and 48. It seems that the commoner class (sebri, севри), ${ }^{1}$ living mostly in extended families (or communal households, the so-called zadruga ${ }^{2}{ }^{2}$ succeeded their property according

1 In $14^{\text {th }}$ century Serbian sources sebar (сєЕАрь', commoner) was the general word for

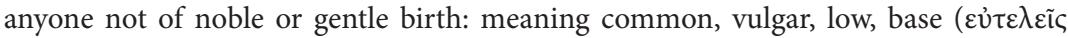
in Greek texts). On the meaning of the word sebar, see Novaković, S., 1886, Die Ausdrücke сєврь, почтен und мєропшинд in der alt serbischen Überzetzung des Syntagma von M. Blastares, Archiv für slavische Philologie, IX, pp. 521-523; Mažuranić, V., 1908-1922, Prinosi za hrvatski pravno-povjestni rječnik, Zagreb, Jugoslavenska akademija znanosti i umjetnosti, pp. 1295-1296, reprint: Mažuranić, V., 1975, Prinosi za hrvatski pravno-povjestni rječnik, Zagreb, Informator; Skok, P., 1973, Etimologijski rječnik hrvatskoga ili srpskoga jezika, uredili akademici Mirko Deanović i Ljudevit Jonke, suradivao u predradnjama i priredio za tisak Valentin Putanec, vol. III, Zagreb, Jugoslavenska akademija znanosti i umjetnosti, p. 210.

2 Besides the immediate family, called inokosna or inokoština ("individual family"), consisting of a father, mother and their children, in Serbian mediaeval law existed also the extended family, called zadruga. A zadruga refers to a type of rural community similar to Roman consortium which is historically common among Southern Slavs. Originally formed by one extended family or a clan of related families, the zadruga held its property, herds and money in common with usually the oldest member (patriarch, Serbian starešina, сйарешина, pater familias of Roman consortium) ruling and making decisions for the family. Though at times he would delegate this right at an old age to one of his sons. Within the zadruga, all family members worked to ensure that the needs of every member were met. Serbian charters from the $13^{\text {th }}$ and $14^{\text {th }}$ century charters mention zadruga without using that term. The expression designating extended family was kuća, meaning house.

Vuk Stefanović Karadžić (1787-1864), philologist and linguist, major reformer of the Serbian language in Karadžić, V. S., 1852, Serbian Dictionary, Paraleled with German and Latin Words (Срйски рјечник истиммачен ғемачкијем и тайинскијем ријечима), Vienna (reprint Karadžić, V. S., 1971, Serbian Dictionary, Paraleled with German and Latin Words, Belgrade, Prosveta - BIGZ), P. P. Armeniern, explained zadruga as Hausgenossenschaft, plures familiae in eadem domo (p. 173). On zadruga see also Peisker, J., 1900, Die Serbische Zadruga, Zeitschrift für Sozial-und Wirtschaftgeschichte, 7, pp. 211-326 and Nedeljković, B., 1937, Postanak zadruge (Genesis of Zadruga), Pravna misao - časopis za pravo i sociologiju, br. 11-12 u čast Živojina Perića, god. 3, 11-12, pp. 595-604 = Nedeljković, B., 2005, Selected Works of Branislav Nedeljković, Šuković, M., Bogojević Gluščević, N. (eds.), Podgorica, Pravni fakultet, pp. 453-462.

Serbian lawyer Jovan Hadžić (1799-1869), the author of the Serbian Civil Code (Срйски ірађански законик) of 1844, defined extended family (zadruga) as follows. Article 507: Zadruga exists wherever a community of life and property is established and determined by ties of blood relationship or adoption (3agpyīa je orge, ige je

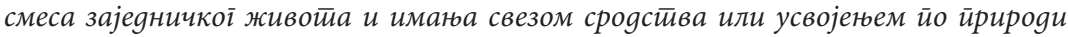
основана и уишврђена); article 508: All real estate and property found within a zadruga 
to the rules of customary law, while the noblemen have accepted provisions of Byzantine law.

In Serbian legal miscellanies translated from Greek, the institutions of testate and intestate succession were rather thoroughly presented. The socalled Zakon gradski (Қаконі градски;, Serbian translation of Procheiron) ${ }^{3}$ contains the following chapters referring to the law of succession: Chapter 21, On the will of persons not under the patria postestas (

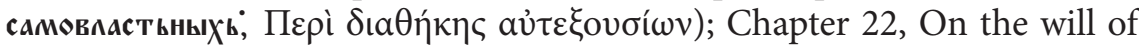

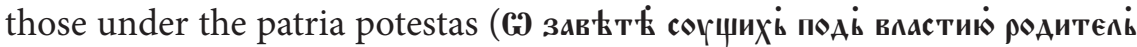

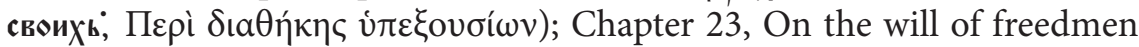

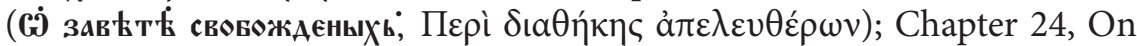
the will of bishops and monks (๗j зав

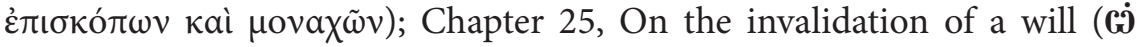

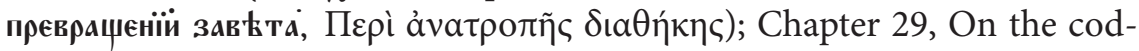

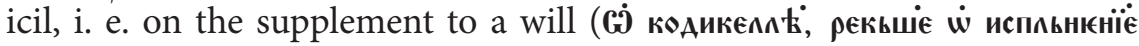

is not owned by one person but by all; and anything one person living in a zadruga acquires, is not acquired for his own self but for all (Шїо је ìg имань и gобара y заярузи, није јеgноїа но свију, и шито іол који у заgрузи иррибави, није себи но свима је йрибавио). The fact that $19^{\text {th }}$ century Civil Code regulated zadruga means that such kind of extended family still existed in Serbia and Hadžić dedicated to it Chapter XV (articles 507-529), entitled On the Law of Succession and Relations in Zadruga (О наслеgним иравима и оgносима у заgрузи). We have to remark that Austrian Civil Code (Österreichs Allgemeines Bürgerliches Gesetzbuch) of 1811, which was the role model for Serbian Civil Code, does not contain a chapter concerning zadruga. See Avramović, S., The Serbian Civil Code of 1844: A Battleground of Legal Tradition, in: Simon, T., Bender, G., Kirov, J. (eds.), 2017, Konflikt und Koexistenz. Die Rechtsordnungen Südosteuropas im 19. und 20. Jahrhundert, Band II, Serbien, Bosnien-Herzegowina, Albanien, Frankfurt am Main, Verlag Vittorio Klostermann, pp. 379-482.

3 Zakon gradski is Chapter 55 of the Nomokanon or Zakonopravilo of Saint Sabba (or Sava, Serbian Cyrillic Свети Сава), the first Byzantine legal miscellany that came to Serbia, around 1219. On his way back from Nicaea (Níkaıa, modern İznik in Turkey), where the Serbian Church got its autocephalous, Sabba stopped in Thessaloniki where he probably composed the famous Nomokanon or Krmčija (from Russian Кормчая книї, literally The Pilot's Book). The ecclesiastical rules of the Krmčija were taken from two Byzantine canonical collections, with canonist's glosses: the Synopsis ( $v^{\prime} v o \psi(\varsigma)$ of Stephen from Ephesos (beginning of the $6^{\text {th }}$ century), with the in-

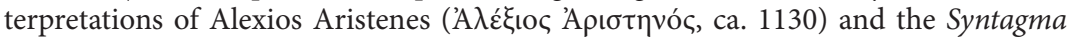

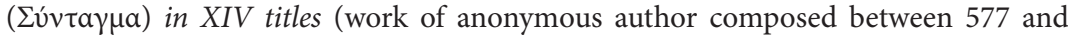

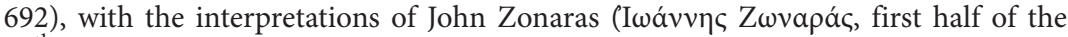
$12^{\text {th }}$ century). Among the Roman (Byzantine) laws (vó ${ }^{\circ o}$ ), St Sabba's Nomokanon

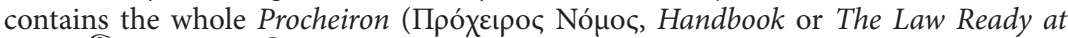
Hand, ḧаконд градскаго главъ in the Serbian translation), ordered in 907 by Emperor Leo VI and a translation of 87 titles of Justinian's Novels (Collectio octoginta septem capitulorum). The author of this collection, completed before 565, was the Patriarch

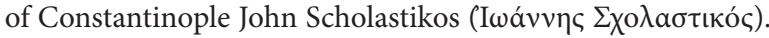




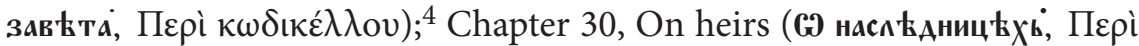

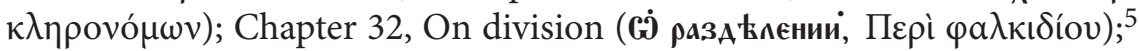

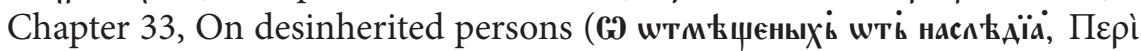

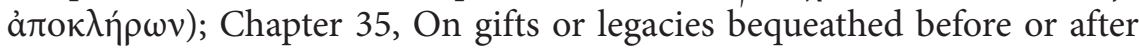

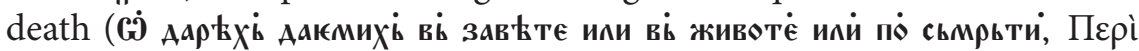

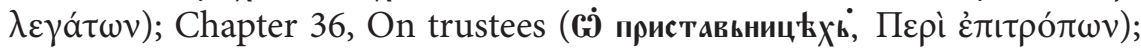
Chapter 37, On when creditors should take action against heirs (@) томі

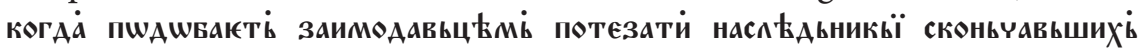

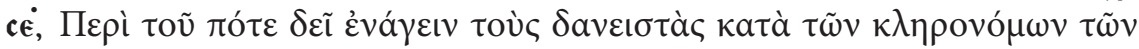
$\tau \varepsilon \lambda \varepsilon v \tau \eta \sigma a ́ v \tau \omega v) .{ }^{6}$ Syntagma, a nomokanonik miscellany put together in 24 titles (each title is labelled by a sign of one of the letters of the Greek alphabet) by the monk Matheas Blastares from Thessaloniki, and came to be known in Serbia in a full and abridged edition. Matheas Blastares placed all provision on intestate and testate succession in the same chapter $(\mathrm{K}-12)$ under the title On heirs and the disherison of sons or par-

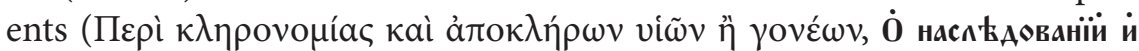

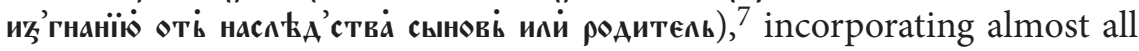
rules from the Procheiron.

4 In Roman law, the codicil represents a separate document (table) wherein was entered a legacy in case it was not included in a will. However, the Procheiron defines the codicil as a supplement (amendment) to a will, being the consequence of insufficient reflection on the side of a testator. Procheiron XXIX, 1, edited by Zepos, P., Zepos, J.,

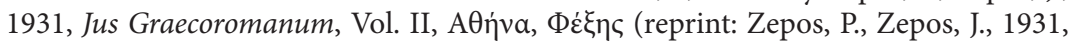

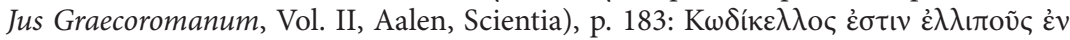

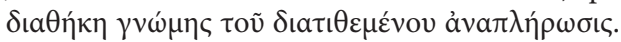

5 The Greek term $\varphi \alpha \lambda \kappa i ́ \delta ı$ o originates from the lex Falcidia, promulgated in $40 \mathrm{BC}$, providing for a maximum of three quarters of a person's estate to be bestowed as a legacy, entitling an heir to at least a quarter of the inheritance (Gaius, Institutiones II, 227: Lata est itaque lex Falcidia, qua cutum est, ne plus ei legare liceat quam dodrantem, itaque necesse est, ut heres quartam partem hereditatis habeant). Justinian's Novella XVIII, 1, issued in 536, provided that this part had to be one third of the inheritance, if a testator had up to four children, and half, if a testator had more than four children. Nevertheless, the term $\varphi a \lambda \kappa_{i} \delta$ เo ding of the Procheiron's chapter XXXII.

6 Edited by Dučić, N., 1895, Književni radovi, Beograd, Državna štamparija Kraljevine Srbije, knjiga 4, pp. 323, 327, 329, 330, 331, 345, 346, 353, 355, 377, 378, 379; Zepos, P., Zepos, J., 1931, pp. 167, 170, 171, 172, 173, 183, 188, 189, 203, 204, 205; edited by Petrović, M., 1991, Zakonopravilo ili Nomokanon Svetoga Save, Ilovički prepis 1262. godina, Gornji Milanovac, Dečje novine, pp. 294 b, 296 a, 296 b, 297a, 297 b, 303 a, 305 b, 306 b, 314 b, 315 a, 315 b.

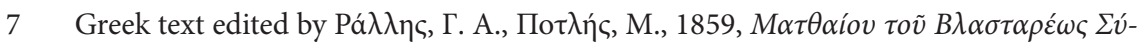

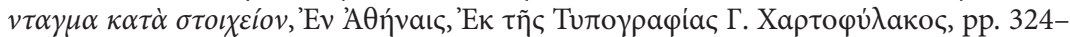
329 (reprint 1966). Serbian translation edited by Novaković, S., 1907, Matije Vlastara Sintagmat, Azbučni zbornik vizantijskih crkvenih i državnih zakona i pravila, slovenski prevod vremena Dušanova, Beograd, Srpska Kraljevska Akademija, pp. 342-347. 


\section{Intestate Succession}

\subsection{BYZANTINE LAW ON INTESTATE SUCCESSION}

Byzantine Law on intestate succession, especially Procheiron and

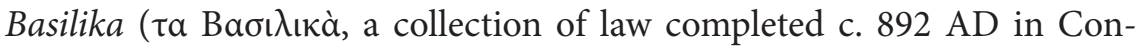
stantinople by order of the Byzantine Emperor Leo VI the Wise), kept all the basic principles of Justinian's legislation. ${ }^{8}$ However, the intention to limit the right of collaterals in a remoter degree to take inheritance is evident. Restriction was usually done in favour of the Church. So, Emperor Constantine VII Porphyrogennetos ordered (Novella XII, between 945959) that in the case where there are no heirs of whole blood, one third of inheritance had to be given to the Church ("given for the soul", $\delta \omega \rho \varepsilon \tilde{\sigma} \theta a \mathrm{I}$ $\psi v \chi \tilde{\eta} \varsigma) .{ }^{9}$ In the year 1306, the Patriarch Athanasios and the Council (Syn-

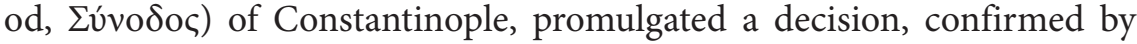
the Emperor Andronikos II Palaiologos (Novella XXVI), that from the inheritance of the serfs one third will be given to the Church ("for the soul"), one third to the landlord and only one third to the heirs. If there were no heirs, inheritance would be divided between the landlord and the Church. A second conclusion of the same Council ordered that in the case of death of under age person, who already had inherited deceased parent, heritage would be divided into three parts: one third to the remaining parent, one

8 By Novella CXVIII (A.D. 543) and Novella CXXVII (A.D. 548) Justinian refashioned the order of succession. The result of this was: a) Agnation was replaced by a relationship based on the blood tie; b) Males and females were treated equally; c) A new order of succession appeared, consisting of four classes. Earlier classes excluded later ones where members of an earlier class were unable or unwilling to accept, persons within the next class could claim.

1) Descendants - This class included those emancipated and not emancipated, adopted or natural, male and female. Those who succeeded in the first degree took per capita; those in a remoter degree took per stirpes. Nearer descendants excluded the more remote.

2) Ascendants and brothers and sisters of the whole blood - Parents shared with brothers and sisters of the whole blood. A grandparent succeeded only where brothers, sisters and parents did not take. The child of a dead brother or sister represented its parents.

3) Brothers and sisters of a half blood - Their children could take by representation.

4) All other collaterals - Those in the same degree took per capita. There was no representation.

The next class to take would be husband and wife. They were not included in the Novellae of 543 and 548, but were mentioned in this connection in the Basilika. See Curzon, L. B., 1966, Roman Law, London, MacDonald \& Evans, pp. 125-126.

9 Zepos, P., Zepos, I., 1931, Jus Graecoromanum, Vol. I, pp. 235-238. 
third to the parents of deceased parent and one third to the Church. The provision was valid for all social classes. ${ }^{10}$

\subsection{SERBIAN SOURCES}

Serbian sources mention only intestate succession of hereditary estates, belonging to the noblemen class. For example, King Milutin's charter presented to the Žaretić (Lovretić) family from the City of Bar (summer 1316), confirms the right of inheritance of the Žaretić (Lovretić) nobleman family, saying that their ascendants had the same right

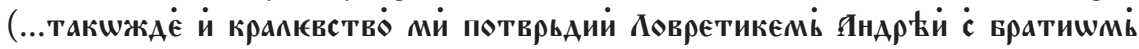

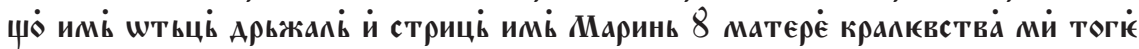

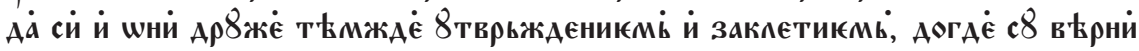
крапкветв 8 ми....). ${ }^{11}$

Article 41 of Dušan's Law Code states: If any lord have no child, or if he have and it die, then upon his death the inheritance remains empty until there be found someone of his kin up to the third cousin, ${ }^{12}$ and to him shall

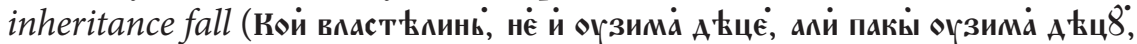

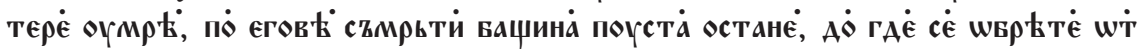

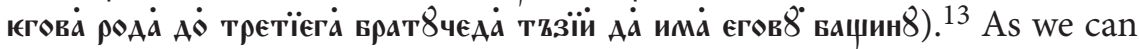
see, first heirs were children, male and female. It appears that in Serbia there was no form of Salic Law of non-limited inheritance in the male line. ${ }^{14}$ Collaterals can inherit "up to the third cousin", which is transla-

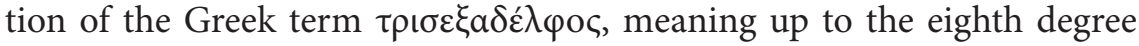
of a blood relationship. The expression could be found in the Syntagma of Matheas Blastares (B - 8): Marriage is allowed in the eighth degree of a blood relationship. It is not forbidden to take the third cousin or grand-

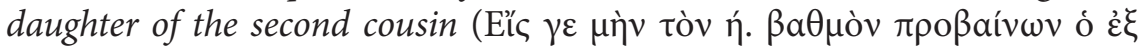

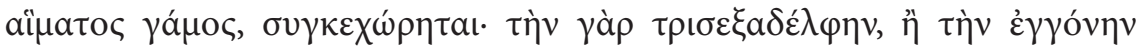

10 Ibid., pp. 533-536.

11 Edited by Božanić, S., 2007, Povelja kralja Milutina barskoj porodici Žaretića, Stari srpski arhiv, 6, Beograd, Univerzitet u Beogradu, Filozofski fakultet, p. 12.

12 The Serbian word is bratučed (Serbian Cyrillic братучед, lit. "brother's child“) and it includes nieces as well as nephews.

13 Burr, M. (transl. from the Old Serbian with Notes), 1949-50, The Code of Stephan Dušan, Tsar and Autocrat of the Serbs and Greeks, Slavonic (and East European) Review, 28, p. 206; Novaković, S., 1898, Zakonik Stefana Dušana, cara srpskog, Beograd, Zadužbina Ilije M. Kolarca, p. 37 (reprint 2004); Pešikan, M., Grickat-Radulović, I., Jovičić, M., 1997, Izvori srpskog prava, IV: Zakonik cara Stefana Dušana, Vol. III, Beograd, Srpska akademija nauka i umetnosti, Odeljenje društvenih nauka, Beograd, p. 110.

14 See also article 48 of the Code which permits a daughter to sell her jewels and raiment inherited from her father. 


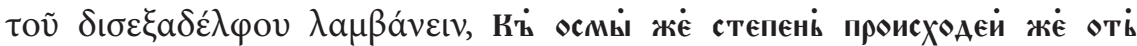

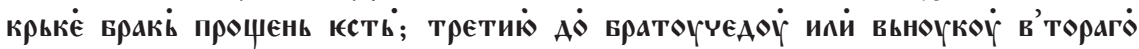

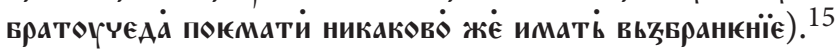

Inheritance without an heir was called "withered" (wАоумрьтна) and it belonged to the monarch. The Law Code of Stefan Dušan does not explicitly define such an arrangement, but in the Tsar's chrysobull confirming the founding of Episcopate of Zletovo (1346, September 1 - 1347, August 31), ${ }^{16}$ we read: Kraimir's water-mill which remained withered, $M y$

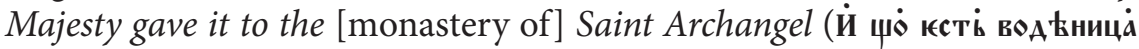

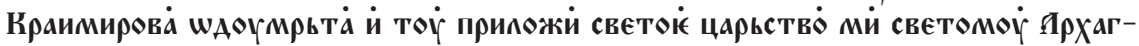
геnоy). ${ }^{17}$ So, a water-mill that was a hereditary estate of a certain Kraimir, remained without heirs. As the Tsar had hereditary rights on it, he took a water-mill and gave it as a present to the Church.

Article 48 runs as follows: And when a lord dies, his good horse and arms shall be given to the Tsar, and his great robes of pearls and golden girdle, let his son have them and let them not be taken by the Tsar: and if he have no son, but have a daughter, then his daughter is free to sell or give

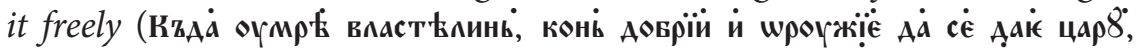

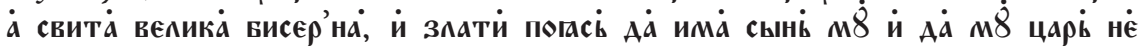

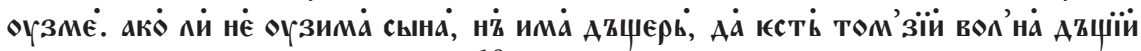
и продати или шаати своводно). ${ }^{18}$ The surrender of the horse and arms of a lord on his death to the monarch is what in English law was termed heriot - a customary tribute of goods and chattels payable to the lord of the fee on the decease of the owner of the land. "A good horse" would be the "best horse" corresponding to the "best chattel" of the English law of heriot. The horse and weapons would be conferred afresh upon his successor, if male of age. ${ }^{19}$ However, article 48 belongs more in a matter of public law. ${ }^{20}$

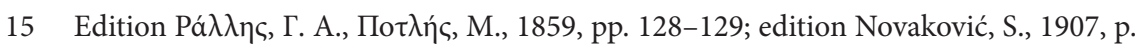
133.

16 This document was created as a consequence of a decision made by State Council held in Skopje in 1347. It was then when it was decided to establish Episcopate of Zletovo with a seat at monastery of Saint Archangels in Lesnovo, endowment of Despot Jovan (John) Oliver. Zletovo (Serbian Cyrillic Злетово) is today a village in the Municipality of Probištip of North Macedonia.

17 Edited by Mišić, S., 2014, Hrisovulja cara Stefana Dušana o osnivanju Zletovske episkopije, Stari srpski arhiv, Univerzitet u Beogradu, Filozofski fakultet, 13, Beograd, p. 186.

18 Burr, M., 1949-50, p. 207; Novaković, S., 1898, p. 42; Pešikan, M., Grickat-Radulović, I., Jovičić, M., 1997, p. 112.

19 Cf. Burr, M., 1949-50, p. 207, comment of the article 48.

20 See Kovačević, J., 1952, Član 48 Dušanovog zakonika i insignije (Article 48 of Dušan’s Law Code and Insignia), Istoriski časopis: organ Istoriskog instituta SAN, 3, pp. 466468; Božić, I., 1956, Konj dobri i oružje (uz član 48 Dušanovog zakonika) [Good horse 
According to some fragments from Serbian charters we can conclude that the estates could be inherited even in a commoner's class. For example, King Stefan Uroš III's chrysobull, presented to the monastery of Dečani (1330), says that the inheritance right of certain protopope (Greek $\pi \rho \tilde{\omega} \tau o \varsigma=$ first, and Serbian $p o p=$ priest, literally "chief priest") Prohor and his sons and grandsons and great-grandsons were "written and con-

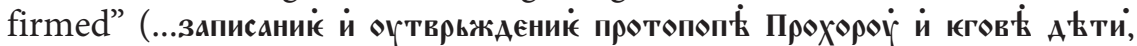
и в'ноучию и прьв' ногчию). ${ }^{21}$ In the crysobull issued to the Saint Archangels' monastery near a City of Prizren (1348), Tsar Dušan says that he settled some masons and gave them lands as a hereditary estate, to them

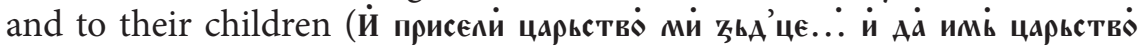

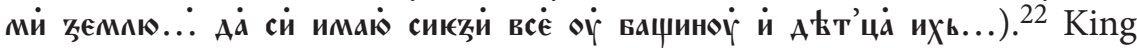
Milutin's charter giving privileges to the monastery of Saint Stephen in Banjska (promulgated after February 8, 1314 - before March 12, 1316), says that a widow, who has a little boy, should hold the whole village until

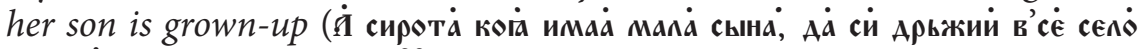
Аөг'А $\dot{\mathbf{t}}$ ки сині подрасте). ${ }^{23}$ It is perfectly clear that villager's estate could be succeeded in the first degree - males only. Collaterals could not inherit because they were mostly living in so-called zadrugas (extended families) and they had their own lands. ${ }^{24}$

\section{Testate Succession}

\subsection{THE CONCEPT OF THE WILL}

Though the concepts of will and testament had been known to the Romans from the time of the Twelve Tables, and Roman lawyers discussed this legal institute at large, there is only a single definition of it. It was

and arms (on the article 48 of Dušan's Law Code)], Zbornik Matice srpske za društvene nauke, 13-14, Novi Sad, pp. 85-92. See also the article "Konj” (Mihaljčić, R.), Ćirković, S., Mihaljčić, R., 1999, Leksikon srpskog srednjeg veka, Beograd, Knowledge, pp. 314-315.

21 Edited by Ivić, P., Grković, M., 1976, Dečanske hrisovulje, Novi Sad, Institut za lingvistiku, p. 264.

22 Edited by Mišić, S., Subotin-Golubović, T., 2003, Svetoarhanđeloska hrisovulja, Beograd, Istorijski institut, p. 110.

23 Mošin, V., Ćirković, S., Sindik, D., 2011, Zbornik srednjovekovnih ćiriličkih povelja $i$ pisama Srbije, Bosne i Dubrovnika, knjiga I, 1186-1321, Beograd, Istorijski institut, p. 465.

24 Taranovski, T., 1931-1935, Istorija srpskog prava u nemanjićkoj državi, Vol. III, Beograd, Geca Kon, pp. 121-122 = reprint: Taranovski, T., 1996, Klasici jugoslovenskog prava, knjiga 12, Beograd, Službeni glasnik, pp. 666-667. 
presented by the lawyers of Justinian at the beginning of the first chapter of book XXIII of the Digests, entitled Qui testamenta facere possunt et quemadmodum testamenta fiant. This is the fragment from Modestinus from the second book of his Pandectae (libro secundo pandectarum): Testamentum est voluntatis nostrae iusta sententia de eo, quod quis post mortem suam fieri velit, ${ }^{25}$ meaning that a will is the legal statement of a person's wish concerning what is to be done after his death. Modestinus' text also found its way to both the Procheiron and the Basilika, the

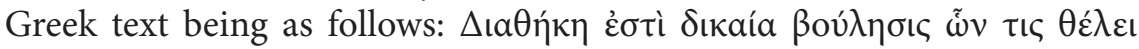

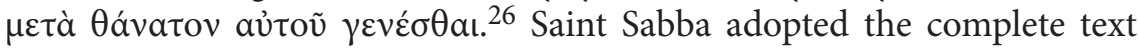
of the Procheiron (Законі градиски in Slavonic), and in both the Greek and Slavonic texts Modestinus' definition is found at the beginning of Chapter

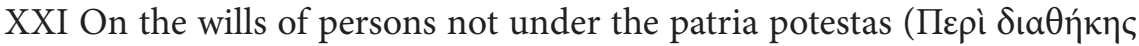

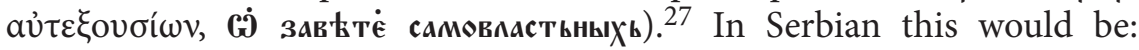

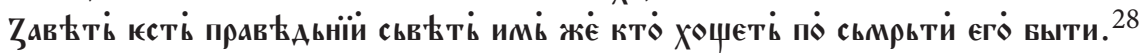
This rule was likewise incorporated into Matheas Blastares Syntagma, also translated into Serbian, with a slightly different Slavonic translation:

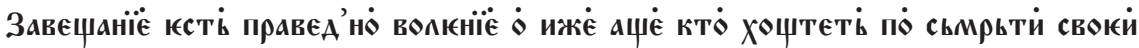
оүстрокномі выти. ${ }^{29}$

Thus, in transferring the term will into Serbian, the translators used both the words завьтті and завєщанії, ${ }^{30}$ with these terms referring to a promise or a bequest in the general sense. ${ }^{31}$ The editors of Serbian legal miscellanies moreover synonymously used the Greek calque диатаз̆іи ( $\delta ı$ á $\tau \alpha \xi ı)$. Therefore, e.g. part Д - 4 of the Serbian translation of the Complete Syntagma was entitled $\dot{\mathbf{0}}$ қавєщаній, while in the table of contents the title of that section was marked as $\dot{0}$ зав

25 D. XXVIII, 1, 1.

26 Procheiron XXI, 1 = Basilika XXXV, 1, 1.

27 Zepos, P., Zepos, J., 1931, p. 167; Dučić, N., 1895, p. 323; Petrović, M., 1991, 294 b.

28 Dučić, N., 1895, p. 323; Petrović, M., 1991, p. 294 b.

29 Novaković, S., 1907, p. 217.

30 The exceptions are two surviving wills: one of a peasant from the vicinity of Dubrovnik and the other from Bosnian Herzeg (Duke) Stepan Kosača, dated $28^{\text {th }}$ May, 1466, both using the term testament (тесьтанєньть; тестамєнат, variant spelling). See Solovjev, A., 1926, Odabrani spomenici srpskog prava, Beograd, Geca Kon, pp. 177, 220, 225. In the will of Vlahuša Kuljašić from Yanina (March 1491), carved in Ston (Italian Stagno, today a city and municipality in the Dubrovnik-Neretva county of Croatia) we see the formula: Vlahuša Kuljašić during his life leaves by will his mi-

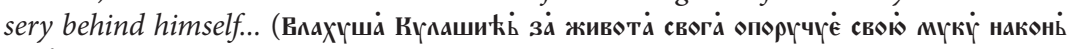
сєвє....). Solovjev, A., 1926, p. 227.

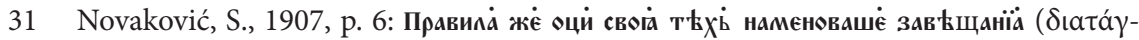

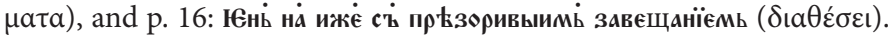


e. diataxes). ${ }^{32}$ Article 2 of the so-called "Justinian's Law"33 begins with the

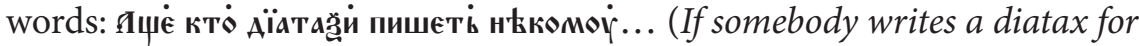
someone.... $)^{34}$ and likewise in the charter of Despot Đurađ Branković, issued in 1428-1429 and confirming the hereditary estate to the great headman (veliki čelnik) Radič, it was written: ...записавши мог оу свой дїатась (...written in his diatax). ${ }^{35}$

Almost all provisions of the Procheiron on testate succession were incorporated in Matheas Blastares' Syntagma and it Serbian translation: Chap-

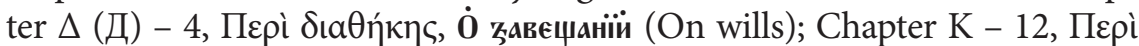

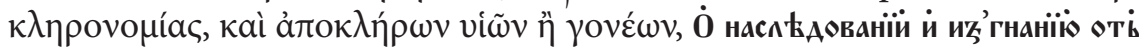
насльд'ства сынові ипи родителі (On heirs and the disherison of sons or par-

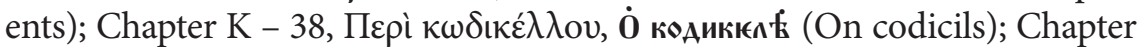

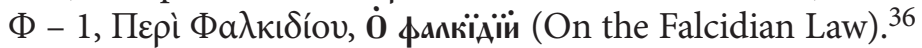

\subsection{SERBIAN SOURCES}

Thus, all of the principles of Graeco-Roman law referring to testate succession are present in Serbian legal miscellanies. Yet which of these actually were applied? The fact is that not a single will remains from that

32 Edition Novaković, S., 1907, pp. 217 and 36.

33 So-called "Justinian's Law" was a short compilation of 33 articles, issued in the first half of $14^{\text {th }}$ century, regulating agrarian relations. The majority of these articles were

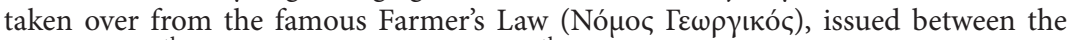
end of the $7^{\text {th }}$ and the beginning of the $8^{\text {th }}$ century. This law had been completely translated into the old Serbian language. Further articles were culled from the Ecloga

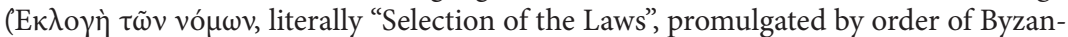
tine Emperor Leo III in 726, or 741), the Procheiron and the Basilika. On the law of wills and succession in "Justinian's Law", compared with the same provisions of the Law Code of Stefan Dušan, see Marković, B., Nasledno pravo u Dušanovom zakoniku i u Zakonu cara Justinijana (Hereditary Right in Dušan's Code and in the Law of Emperor Justinian), in: Ćirković, S., Čavoški, K. (eds.), 2005, Zakonik cara Stefana Dušana, zbornik radova sa naučnog skupa održanog 3. oktobra 2000, povodom 650 godina od proglašenja (Code of Tsar Stefan Dušan, Proceedings of the Conference Held on $3^{\text {th }}$ October 2000, on the Occasion of 650 Years from the Promulgation), Beograd, Srpska akademija nauka i umetnosti, pp. 67-79. The author concludes that so-called "Justinian's Law" contains only two articles pertaining to inheritance (31 and 32) which may be found towards the end of the text. These articles regulate the inheritance rights of spouses without children. Marriage had to be legal.

34 Edited by Marković, B., 2007, Izvori srpskog prava, XV: Justinijanov zakon, srednjovekovna vizantijsko-srpska pravna kompilacija, Beograd, Srpska akademija nauka i umetnosti, Odeljenje društvenih nauka, p. 53.

35 Novaković, S., 1912, Zakonski spomenici srpskih država srednjega veka, Beograd, Srpska Kraljevska Akademija, p. 334.

36 Edition Pá $\lambda \lambda \eta \varsigma$, Г. A., Пот S., 1907, pp. 217, 342, 369, 512. 
time $\mathrm{e}^{37}$ and that there is not one article of Dušan's Law Code mentioning this legal institute - which certainly does not mean that it was unknown in Serbia. "Although probably a large number of inheritances remained undivided as a collective property" ("Мада је вероватно велики део заоставштина остајао у неподељеном задружном власништву”), ${ }^{38}$ individual principles of free disposition over the property included in a will, typical for Graeco-Roman law, are apparent in Serbian legal documents.

Article 40 of Dušan's Code proclaimed the right of noblemen to dispose freely of their inheritances, as well as freedom of testamentation, ex-

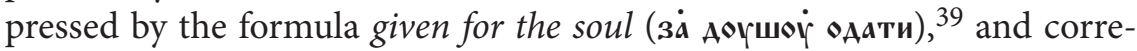
sponded to the capacity to make a will. In a charter issued on the May 28, 1350 , by which Tsar Dušan conferred property on a lesser lord, Ivanko Probištitović, it was said that Ivanko could submit his property freely to

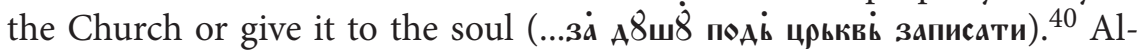
most the same formula can be seen in the charter of Tsar Uroš issued on April 10, 1357, granting Mljet Island (in present-day Croatia) to two noblemen from Kotor, Bivoličić and Bučić: In the same way that I, the Tsar, have confirmed hereditary estates to other lords and lesser lords, thus I confirm this to Baset Barinčelo and to Tripo Miho Bučić and their children, to be confirmed forever, whether they want to submit it to the Church as for the soul, or give it as a dowry, or sell it, or give it as a present, or swap it, and they may act fully of their own discretion as with their own hereditary

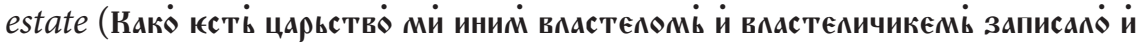

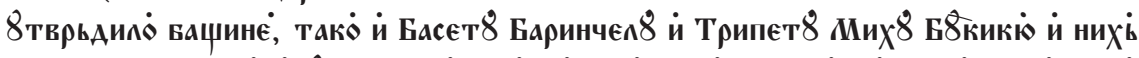

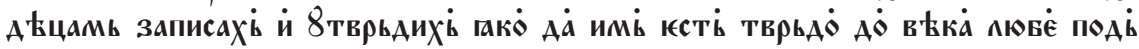
црькөві за А 8 ш8 подьписати 8 прикив аати, продати, Харизати, замћнити,

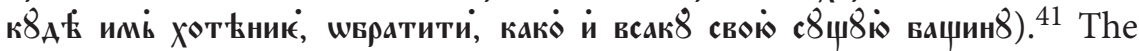
only document where the freedom to dispose by a will was explicitly mentioned was the charter of Despot Đurađ Branković, issued in 1428-1439 in favour of the headman Radič, stating: Let the headman Radič have

37 The exception being several wills of villagers from vicinity of Dubrovnik, as well as the will of Bosnian Herzeg (Duke) Stepan Kosača, but, strictly, these are not sources of Serbian mediaeval law.

38 Solovjev, A., 1928, Zakonodavstvo Stefana Dušana, cara Srba i Grka, Beograd, Štamparija Sveti Sava, p. 139 = reprint Solovjev, A., 1998, Klasici jugoslovenskog prava, knjiga 16, Beograd, Službeni glasnik, p. 447.

39 Burr, M., 1949-1950, p. 206; Novaković, S., 1898, p. 36; Pešikan, M., Grickat-Radulović, M., Jovičić, M., 1997, p. 110.

40 Edited by Aleksić, V., 2009, Povelja cara Stefana Dušana vlasteličiću Ivanku Probištitoviću, Stari srpski arhiv, 8, Beograd, Univerzitet u Beogradu, Filozofski fakultet, p. 73.

41 Edited by Mihaljčić, R., 2004, Mljetske povelje cara Uroša, Stari srpski arhiv, 3, Beograd, Univerzitet u Beogradu, Filozofski fakultet, p. 74. 
possession of these [villages] during his lifetime and if he wants to leave them to anyone after his death by writing this in his will, either to his child or to someone of his relatives, or he may give it to the Church (... А $\dot{a}$ си ихі имаa челникі Радич ог свомі животоу, й пं своой сьмрьтй комоу што оүсхокіє оставити, записавши могі ог свой діатась, илй своемог̆ а оті своихі сьродникі, илй црьквй приложити...). ${ }^{42}$ In the second charter of Despot Đurad Branković, presented in 1429-1430 to the headman (čel$n i k$, чєлникь) Radič, the right to freely make a will is also established, although the word will (диатаз्) was not itself mentioned: ...and after his death he may leave it either to a relative of his or to someone else without

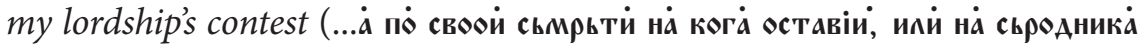

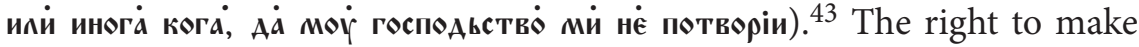
a will, expressed by the formula to leave to one of the relatives (ипи комоу оді своихі оставити), was given by the charter of the Bosnian King Stefan Tomaš to the great logothetes $(\lambda o \gamma o \theta \varepsilon \dot{\tau}\rceil)^{44}$ Stefan Ratković, presented on October $14,1458 .^{45}$

We have information, albeit sparse, that commoners (sebri) also had the capacity to make wills and that they disposed of their property freely. In all those cases, the property was bequeathed to the Church and monasteries and the legal operation was expressed by the formulas "given for

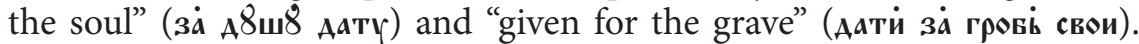
Saint George's charter (1300) mentioned a certain Kalomen, who "gave

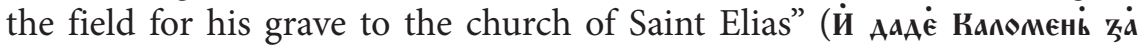
грові свой црькві Светагі Икиі сі нившмь). ${ }^{46}$ In the contract, a certain Dobroslava, with her children, sold her manor in Prizren to Mano (the socalled "Tapiya from Prizren"). Among other things was written that Mano

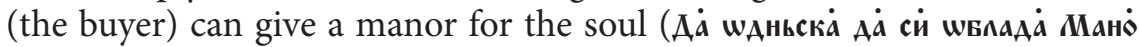

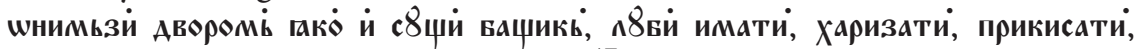
проАати, за А $8 ш 8$ Аатти апи заменити). ${ }^{47}$ We can find some more information in the inventory of the estates of the monastery of the Holy Virgin in Tetovo (ca. 1346), e. g.: The field under Recice between the roads was given by Roman for his grave and for his soul. And the other field, under that one,

42 Novaković, S., 1912, p. 334.

43 Ibid., p. 336.

44 In Byzantium, this was a generic term that in the $9^{\text {th }}$ and $10^{\text {th }}$ century designated a high official at the head of one of many departments with primarily but not exclusively fiscal functions. Under Byzantine influence the title was adopted in Slavonic countries.

45 Ibid., pp. 344-345.

46 Mošin, V., Ćirković, S., Sindik, D., 2011, p. 321.

47 Edited by Bubalo, Đ., 2004, Srpski nomici, Beograd, Vizantološki institut Srpske akademije nauka i umetnosti, p. 250. 
was given by Oubislav for his grave (Нива поді РҺчицами Межаоүпоүтию,

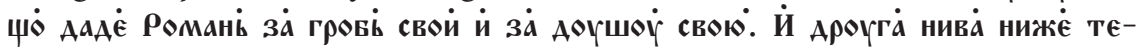

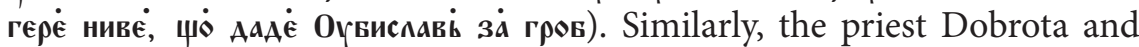
brothers Nikolitza and Hranislav bequeathed their fields "for the grave

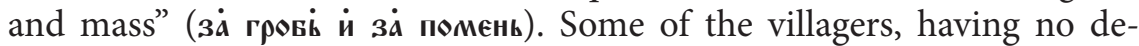
scendants, bequeathed their land to the Church: ... Nanaya gave part of his land for his soul, as he had no descendants... I, Savdik, having realised that I have no descendants... am giving the field under Holy Sunday... in

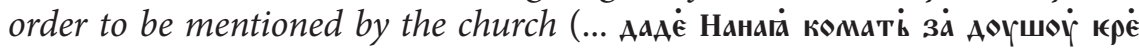

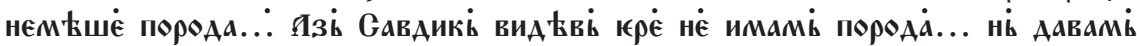

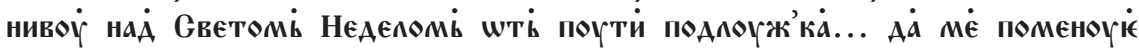
црьква). But the document also mentioned one dispute that had arisen from the fact that a certain Strez bequeathed his land to the Church although he did have a male descendant. Strez's son Dragia and son-in-law Dragoslav brought about an action challenging the will (... ші кетті них

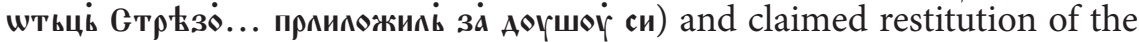
bequeathed property, but when they appeared in front of judge Dabiziv, they were reconciled with one-another and said: 'What our father sold and gave to the Church we do not contest but confirm' (...и ст стопише прtаi

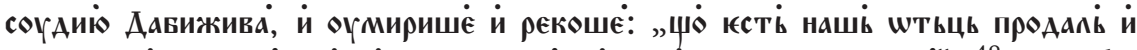
припожилі црьквы, мй не потварамо, ні паче пооүтврьжАамм “). 48 It is obvious that the will of Strez was made in accordance with the governing legal rules of that time and that, therefore, his son and son-in-law did not have any legal ground to challenge it, proven by the expression they were reconciled with one-another (оүмирише) when appearing in court.

Slightly greater influence of Roman law can be observed in the wills of villagers from the vicinity of Dubrovnik. The free disposition over a property is completely in the sense of Graeco-Roman (Byzantine) law and there is even a case of the disherison of a male descendant in favour of a female. The will of Vlahno Radišević from Ston, made on January 8, 1486, states that Vlahno wished to leave everything ...rather to my daughter Nikoleta, from small to large, than to my son Dragoye... who is separated

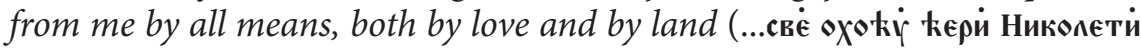

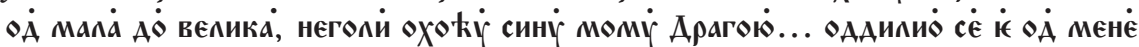
свимь, какі пүвавюе, такї й иманиемь). ${ }^{49}$

We can further ascertain the acceptance of Graeco-Roman law from the will of Medoye Nikulin, dated to the February 23, 1392, the beginning of which is as follows: Medoye the son of Nicholas from the county of

48 Mošin, V., Slaveva, L., Miljković-Pepek, P., 1980, Spomenici za srednovekovnata i ponovata istorija na Makedonija, Vol. III, Skopje, Arhiv na Makedonija, p. 297.

Solovjev, A., 1926, pp. 225-226. 
Žrnovnica, from Zavrilje, being strongly disabled, but still of good mental health, is going to make his will (Медоё сині Николині из жоүпе

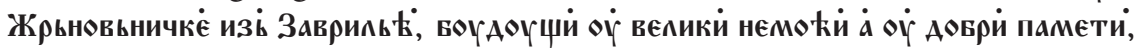
оүчини свой тесьтаменьть). ${ }^{50}$ In this case, we have the old principle of Roman law that mental, not bodily health, was required as a prerequisite for making a will. This principle was formulated by the Roman lawyer Labeon as follows: In eo qui testatur eius temporis, quo testamentum facit, integritas mentis, non corporalis sanitas exigenda est. ${ }^{51}$ This rule was also incorporated into the Procheiron and the Basilika, its text in Greek being:

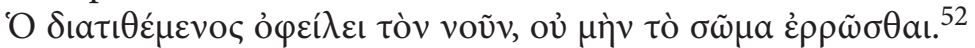

The same document mentions the institute of Byzantine law called

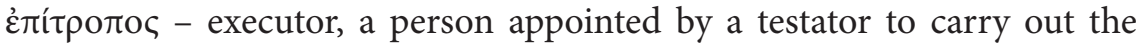
directions and requests in his will, and to dispose of the property according to his testamentary provisions after his decease. ${ }^{53}$ At the end of the testament Medoye Nikulin says: And executors are Bogavatz, comes [of the county] Žrnovički and Milan Gurinovišt from the city (i் томог cor притропи Богаваці кнезь Жрьновьничьки й Миилані Гүриновичі изі граАа). ${ }^{54}$ Four chapters of the Statute of Kotor mention also executors of a will

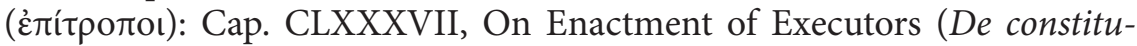
tione Epitroporum), Cap. CLXXXVIII, On Authorization of Executors (De potestate Epitroporum), Cap. CLXXXIX, On Executors of those who leave heirs under age (De epitropis illorum qui relinquunt heredes infra etatem legitimam) and Cap. CXC, On sales done by Executors (De venditione epitroporum). 55

Strictly, all of these testaments cannot be considered Serbian mediaeval legal documents, therefore conclusions on the application of the rules of Roman-Byzantine law in mediaeval Serbia cannot be made with certainly. ${ }^{56}$

\section{$50 \quad$ Ibid., p. 177.}

51 D. XXVIII, $1,2$.

52 Procheiron XXI, 2; Basilika XXXV, 1, 2. The Serbian translation of the text (Dučić,

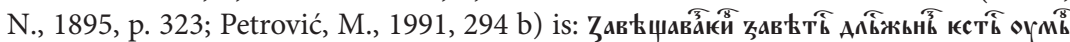

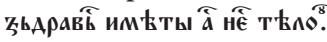

53 On executors in Byzantine law, especially in the Holy Mountain's documents see

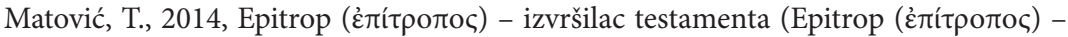
Executor of a Will), Zbornik radova Vizantološkog instituta, 51, pp. 187-214.

54 Solovjev, A., 1926, p. 178.

55 Milošević, M. et al., 2009, Statuta civitatis Cathari - Statut grada Kotora, Knjiga I, fototipsko izdanje originala iz 1616. godine; knjiga II, prevod originala iz 1616. godine sa naučnim aparatom, Kotor, Državni arhiv Crne Gore, pp. 111-114.

56 See Šarkić, S., The Concept of the Will in Roman, Byzantine and Serbian Medieval Law, in: Burgmann, L. (ed.), 2005, Forshungen zur byzantinische Rechtsgeschichte (= Fontes minores, XI), Frankfurt am Main, Löwenklau, pp. 426-433. 


\subsection{GIFT IN CONTEMPLATION OF DEATH}

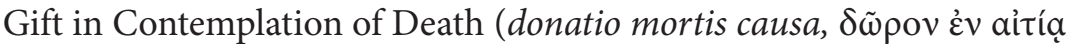
Aavátov) is a gift under apprehension of death; as when anything is given upon condition that, if the donor dies, the donee shall possess it absolutely, or return it if the donor should survive or should repent of having made the gift, or if the donee should die before the donor. A gift in view of death is one which is made in contemplation, fear, or peril of death, and with intent that it shall take effect only in case of the death of giver. ${ }^{57}$

Two forms of a gift in contemplation of death, known from Roman law, could be found in Byzantine legal miscellanies as well. However, Greek terminology is slightly different - indicated by the text of Prochei-

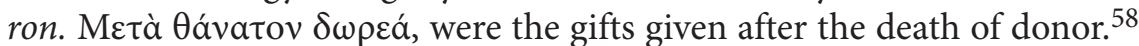
Ownership rights of a donee will be acquired in the moment of donor's death. In the next article, the Procheiron mentions "¿̉v aitía $\theta$ avátov $\delta \omega \rho \varepsilon \tilde{\omega}$ " - gifts in contemplation, fear or peril of death, ${ }^{59}$ what is identical with the second form of donatio mortis causa of Roman law. Serbian translation of Procheiron (Zakon gradski) follows the Greek original using

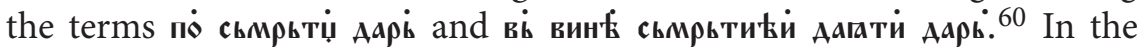
chapter $\Delta(A)-13$, dedicated to gifts, ${ }^{61}$ Matheas Blastares does not mention gifts in contemplation of death. ${ }^{62}$

In legal documents written in old Serbian, we can find some examples which could be considered as gifts in contemplation of death, although sources do not use this term. In the chrysobull presented to the monastery of Saint Archangels Michael and Gabriel (1348), Tsar Dušan says that his lesser lord Nicholas Utoličić gave as a present his hereditary

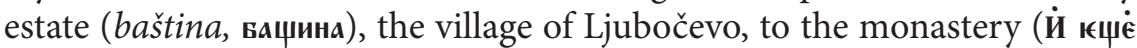
припожй пювовній властеличикі царьства мй Николӓ Оүтоличикі село своі вачин'но Хювочево...). Nicholas and his mother shall hold the village of

57 Cf. D. XXXIX, 6, 2; XXXIX, 6, 35, 4.

58 Procheiron XII, 3, Zepos, P., Zepos, J., 1931, p. 150.

59 Procheiron XII, 4, Zepos, P., Zepos, J., 1931, pp. 150-151. Cf. Ecloga IV, 3, 1: ...ঠı̀̀

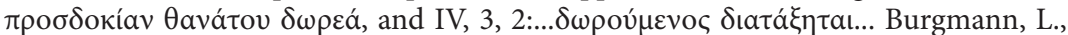
Ecloga, das Gesetzbuch Leons III. und Konstantinos' V. (= Forschungen zur byzantinishen Rechtsgeschichte, Band 10), Simon, D. (ed.), 1983, Frankfurt am Main, Löwenklau, p. 186.

60 Dučić, N., 1895, p. 297; Petrović, M., 1991, pp. 314 a - 314 b.

61 See Chapter III, contracts, 3.

62 See Matović, T., META $\Theta$ ANATON $\triangle \Omega P O N$ u svetogorskim aktima (META $\Theta A N A-$ TON $\Delta \Omega P O N$ in Holy Mountain Acts), in: Miljković, B., Dželebdžić, D. (eds.), 2015, ПЕPIBO $\Lambda \mathrm{O} \Sigma$, Mélanges offerts à Mirjana Živojinović, Vol. II, Belgrade, Vizantološki institut Srpske akademije nauka i umetnosti, pp. 427-442. 
Ljubočevo as long as they live, and after their death the donee (monastery of Saint Archangels) shall acquire the ownership rights over that gift

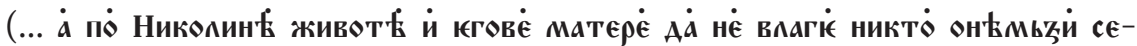

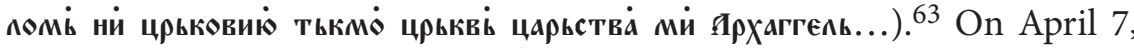
1453, at a market-place in Kosovo, a certain Novak and his spouse Yela gave a half of their house to the monastery of Saint Paul, but the monastery shall acquire the ownership rights over the house after the donors' death (Новакі $\dot{c}$ мокемі подьрджикмі Юломй, нашшмі волшмі й нашимі

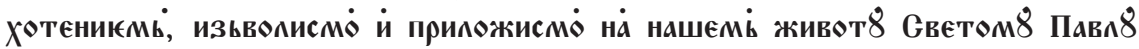

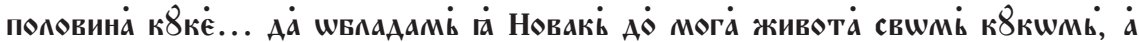

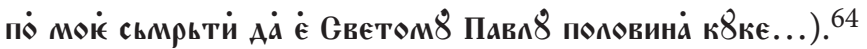

\section{Conclusion}

Serbian mediaeval law contains limited data on the law of wills and succession. The noble class accepted the provisions of Byzantine law, while commoners (sebri), living mostly in extended families (so-called zadruga), inherited their property according to the rules of the customary law.

Byzantine legal miscellanies, translated into mediaeval Serbia from Greek language, contain the basic principles of succession taken from Roman law, but it is disputable to what extent they were applied.

Not a single will remained from mediaeval Serbia. However, a freedom of disposition by testament was expressed by formula "given for the soul" ( $z a$ dušu otdati). Terms, using for will were "zavet" and "zaveštanije", as well as the Greek word diatax or diatas.

\section{BIBLIOGRAPHY}

1. Avramović, S., The Serbian Civil Code of 1844: A Battleground of Legal Traditions, in: Simon T., Bender G., Kirov J. (eds.), 2017, Konflikt und Koexistenz, Die Rechtsordnungen Südosteuropas im 19. und 20. Jahrhundert, Band II, Serbien Bosnien-Herzegowina, Albanien, Veröffentlichungen des Max-Planck-Instituts für europäische Rechtsgeschischte, Band 305, Frankfurt am Main, Verlag Vittorio Klostermann.

2. Božić, I., 1956, Konj dobri i oružje (uz član 48 Dušanovog zakonika), Zbornik Matice srpske za društvene nauke, 13-14, Novi Sad.

3. Curzon, L. B., 1966, Roman Law, London, Macdonald \& Evans LTD.

63 Edited by Mišić, S., Subotin-Golubović, T., 2003, p. 98.

64 Bubalo, Đ., 2004, p. 261. 
4. Karadžić Stefanović, V., 1852, Srpski rječnik istumačen njemačkijem i latinskijem riječima, u Beču u štampariji jermenskoga namastira (reprint Karadžić Stefanović, V., 1972, Srpski rječnik istumačen njemačkijem i latinskijem riječima, Beograd, Prosveta - BIGZ).

5. Kovačević, J., 1952, Član 48 Dušanovog zakonika i insignije, Istoriski časopis: organ Istoriskog instituta SAN, 3.

6. Marković, B., Nasledno pravo u Dušanovom zakoniku i u Zakonu cara Justinijana, u: Ćirković, S., Čavoški, K. (eds.), 2005, Zakonik cara Stefana Dušana, Zbornik radova sa naučnog skupa održanog 3. oktobra 2000. povodom 650 godina od proglašenja, Beograd, Srpska akademija nauka i umetnosti, Odeljenje društvenih nauka.

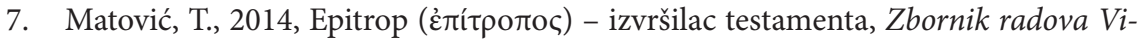
zantološkog instituta, 51.

8. Matović, T., META $\Theta A N A T O N \triangle \Omega P O N$ u svetogorskim aktima, in: Miljković B., Dželebdžić D. (eds.), 2015, ПEPIBO $\Lambda \mathrm{O} \Sigma$, Mélanges offerts à Mirjana Živojinović, Beograd, Vizantološki institut Srpske akademije nauka i umetnosti.

9. Mažuranić, V., 1908-1922, Prinosi za hrvatski pravno-povjestni rječnik, Zagreb, Jugoslavenska akademija znanosti i umjetnosti (reprint: Mažuranić, V., 1975, Prinosi za hrvatski pravno-povjestni rječnik, Zagreb, Informator).

10. Mihaljčić, R., Konj, in: Ćirković, S., Mihaljčić, R. (eds.), 1999, Leksikon srpskog srednjeg veka, Beograd, Knowledge.

11. Nedeljković, B., 1937, Postanak zadruge, Pravna misao: časopis za pravo i sociologiju, br. 11-12 u čast Živojina Perića, god. 3 = Nedeljković, B., Izabrani radovi Branislava Nedeljkovića, Šuković, M., Bogojević Gluščević, N. (eds.), 2005, Podgorica, Pravni fakultet.

12. Novaković, S., 1886, Die Ausdrücke сєврь', почтен und мєропшинд in der altserbishen Übersetzung des Syntagma von Blastares, Archiv für slavische Philologie, IX.

13. Peisker, J., 1900, Die Serbische Zadruga, Zeitschrift für Sozial-und Wirtschaftgeschichte, 7.

14. Skok, P., 1973, Etimologijski rječnik hrvatskoga ili srpskoga jezika, uredili akademici Mirko Deanović i Ljudevit Jonke, surađivao u predradnjama i priredio za tisak Valentin Putanec, Vol. I-III, Zagreb, Jugoslavenska akademija znanosti i umjetnosti.

15. Solovjev, A., 1928, Zakonodavstvo Stefana Dušana, cara Srba i Grka, Skoplje, Skopsko naučno društvo = Solovjev, A., 1998, Klasici jugoslovenskog prava, knjiga 16, Beograd, Službeni glasnik.

16. Taranovski, T., 1931-1935, Istorija srpskog prava u nemanjićkoj državi, Vol. I-IV, Beograd, Geca Kon = Taranovski, T., 1996, Klasici jugoslovenskog prava, knjiga 12, Beograd, Službeni list.

17. Šarkić, S., The Concept of the Will in Roman, Byzantine and Serbian Mediaeval Law, in: Burgmann, L. (ed.), 2005, Forschungen zur byzantinischen Rechtsgeschichte (= Fontes minors, XI), Frankfurt am Main, Löwenklau. 


\section{PRIMARY SOURCES}

1. Aleksić, V., 2009, Povelja cara Stefana Dušana vlasteličiću Ivanku Probištitoviću, Stari srpski arhiv, 8, Beograd, Univerzitet u Beogradu, Filozofski fakultet.

2. Božanić, S., 2007, Povelja kralja Milutina barskoj porodici Žaretića, Stari srpski arhiv, 6, Beograd, Univerzitet u Beogradu, Filozofski fakultet.

3. Bubalo, Đ., 2004, Srpski nomici, Beograd, Vizantološki institut Srpske akademije nauka i umetnosti.

4. Burgmann, L., Ecloga, das Gesetzbuch Leons III. und Konstantinos' V. (= Forschungen zur byzantinishen Rechtsgeschichte, Band 10) in: Simon, D. (ed.), 1983, Frankfurt am Main, Löwenklau.

5. Burr, M., 1949-1950. (transl. with Notes), The Code of Stefan Dušan, Tsar and Autocrat of the Serbs and Greeks, The Slavonic and East Europian Review, 28, University of London, School of Slavonic and East European Studies.

6. Corpus Iuris Civilis, Vol. I, Institutiones, Krueger, P. (ed.) 1895; Digesta, Mommsen, T. (ed.); Vol. II, Codex Iustinianus, Krueger, P. (ed.); Vol. III, Novellae, Schoell, R., Kroll, G. (eds.), Berolini, Weidmannos.

7. Dučić, N., 1895, Književni radovi, knjiga 4, Beograd, Državna štamparija Kraljevine Srbije.

8. Ivić, P., Grković, M., 1976, Dečanske hrisovulje, Novi Sad, Institut za lingvistiku.

9. Izvori srpskog prava IV: Zakonik cara Stefana Dušana, knjiga III, Baranjski, Prizrenski, Šišatovački, Rakovački, Ravanički i Sofijski rukopis, Pešikan, M., Grickat-Radulović, M., Jovičić, M. (eds.), 1997, Beograd, Srpska akademija nauka i umetnosti, Odeljenje društvenih nauka.

10. Marković, B., 2007, Izvori srpskog prava XV: Justinijanov zakon, srednjovekovna vizantijsko-srpska pravna kompilacija, Beograd, Srpska akademija nauka i umetnosti, Odeljenje društvenih nauka.

11. Mihaljčić, R., 2004, Mljetske isprave cara Uroša, Stari srpski arhiv, 3, Beograd, Univerzitet u Beogradu, Filozofski fakultet.

12. Milošević, M. et. al., 2009, Statuta civitatis Cathari - Statut grada Kotora, Knjiga I, fototipsko izdanje originala iz 1616. godine; knjiga II, prevod originala iz 1616. godine sa naučnim aparatom, Kotor, Državni arhiv Crne Gore.

13. Mišić, S., Subotin-Golubović, T., 2003, Svetoarhanđelovska hrisovulja, Beograd, Istorijski institut.

14. Mišić, S., 2014, Hrisovulja cara Stefana Dušana o osnivanju Zletovske episkopije, Stari srpski arhiv, 13, Beograd, Univerzitet u Beogradu, Filozofski fakultet.

15. Mošin, V., Slaveva, L., Miljković-Pepek, P., 1980, Spomenici za srednovekovnata i ponovata istorija na Makedonija, Vol. III, Skopje, Arhiv na Makedonija.

16. Mošin, V., Ćirković, S., Sindik, D., 2011, Zbornik srednjovekovnih ćiriličkih povelja i pisama Srbije, Bosne i Dubrovnika, knjiga I, 1186-1321, Beograd, Istorijski institut.

17. Novaković, S., 1898, Zakonik Stefana Dušana, cara srpskog, Zadužbina Ilije M. Kolarca, Beograd (reprint Novaković, S., 2004, Zakonik Stefana Dušana, cara srpskog, Beograd, Lirika). 
18. Novaković, S., 1907, Matije Vlastara Sintagmat, Azbučni zbornik vizantijskih crkvenih i državnih zakona i pravila, slovenski prevod vremena Dušanova, Beograd, Srpska Kraljevska Akademija.

19. Novaković, S., 1912, Zakonski spomenici srpskih država srednjega veka, Beograd, Srpska Kraljevska Akademija.

20. Petrović, M., 1991, Zakonopravilo ili Nomokanon Svetoga Save, Ilovički prepis 1262. godina, Gornji Milanovac, Dečje novine.

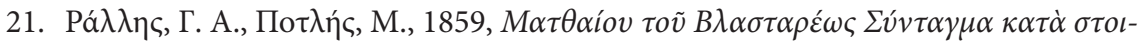

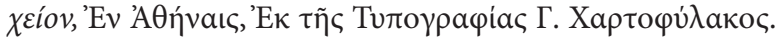

22. Scheltema, H. J., Wal, Van der, N., Holwerda, D., 1953-1988, Basilicorum Libri LX: Seria A, Groningen, J. B. Wolters.

23. Solovjev, A., 1926, Odabrani spomenici srpskog prava, Beograd, Štamparija Sveti Sava.

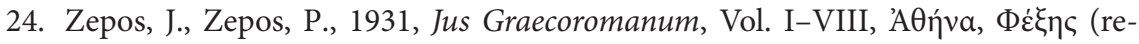
print: Zepos, J., Zepos P., 1962, Jus Graecoromanum, Vol. I-VIII, Aalen, Scientia).

\section{SREDNJOVEKOVNO SRPSKO PRAVO O NASLEĐIVANJU}

\section{Srđan Šarkić}

\section{REZIME}

U srednjovekovnom srpskom pravu imamo vrlo malo podataka o nasleđivanju. Nijedan testament nije sačuvan, a o zakonskom nasleđivanju govore samo članovi 41. i 48. Dušanovog zakonika. Najverovatnije da se sebarsko (nevlasteosko) stanovništvo, živeći u velikim, kolektivnim porodicama (takozvanim „zadrugama“), prilikom nasleđivanja držalo pravila običajnog prava, dok je vladajući sloj (vlastela) prihvatio odredbe vizantijskog prava.

Vizantijsko pravo tretira zakonsko nasleđivanje prema pravilima rimskog prava, korigovanog u dve Justinijanove novele: CXVIII od 543. godine i CXXVII od 548. Te odredbe stigle su i u srednjovekovnu Srbiju sa prevodom vizantijskih pravnih zbirki (Zakonopravilo ili Nomokanon Svetoga Save i Sintagma Matije Vlastara) i nalaze se skupljene u sastavu (poglavlju) K - 12 Sintagme Matije Vlastara. Po svojoj sadržini to su uglavnom propisi preuzeti iz Prohirona, dopunjeni kasnijim carskim novelama. Cilj ovih propisa bio je da se ograniči pravo daljih srodnika na nasledstvo u korist crkve.

Dva člana Dušanovog zakonika koji regulišu nasledno pravo govore samo o nasleđivanju u vlasteoskom staležu. Član 41. predviđa slučaj ako vlastelin umre bez dece. Baštinu nasleđuju pobočni srodnici do osmog stepena srodstva. Prema članu 48, kada umre vlastelin „konj dobri i oružje 
se vraćaju caru" a ostalu imovinu nasleđuju deca, jednako muška i ženska. Vraćanje konja i oružja je stari običaj, koji odražava vazalnu zavisnost vlastele prema vladaru.

O nasleđivanju u sebarskom staležu imamo samo nekoliko razasutih podataka u poveljama. Na osnovu toga teško je reći da li su za sebre postojala jedinstvena pravila o nasleđivanju (Dušanov zakonik o tome ćuti), ili su se razlikovala od vlastelinstva do vlastelinstva.

Propisi o testamentalnom nasleđivanju nalaze se u sastavu D - 4 i K 12 Sintagme Matije Vlastara i odražavaju osnovne principe grčko-rimskog (vizantijskog) prava: sloboda testiranja ograničena je samo takozvanim nužnim delom, što znači da zakonita deca moraju da dobiju minimum trećinu zaostavštine, odnosno polovinu ako je dece više od četvoro. Ne pravi se razlika između muške i ženske dece, a ostavilac može svoje naslednike da isključi iz nasleđa. Forma testamenta je uprošćena, a za punovažnost testamenta dovoljno je od 3 do 5 svedoka. Srpski prevodioci za testament koriste reči zaveštanije i zavet, ali pošto ti izrazi znače i svaki zavet uopšte,

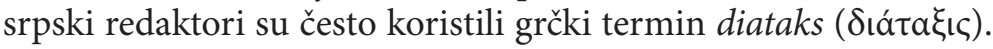

Činjenica da iz srednjovekovne srpske prošlosti nije sačuvan nijedan testament ne znači da je taj pravni institut Srbima bio nepoznat. U Dušanovom zakoniku i poveljama srećemo formulaciju „za dušu otdati“ i „za dušu pod crkov zapisati“, što odgovara pravu testiranja. Neposredni podatak o slobodi testiranja srećemo u povelji kojom 1429. godine despot Đurađ Branković potvrđuje baštinu čelniku Radiču i između ostalog kaže da Radič svoju imovinu može „zapisati u svoj diatas.“

Ključne reči: Dušanov zakonik, Prohiron, „Zakon gradski“, Syntagma Matije Vlastara, testamentalno nasleđivanje, intestatsko nasleđivanje, testament.

Article History:

Received: 17 March 2020

Accepted: 22 May 2020 